\title{
Dva u jedan - pandemija i potres u knjižnicama na području Hrvatske
}

\author{
Alka Stropnik \\ Knjižnice grada Zagreba, Republika Hrvatska \\ alka.stropnik@kgz.hr
}

\begin{abstract}
Sažetak
U 2020. godini dva su razorna potresa pogodila područje Grada Zagreba i Sisačko-moslavačke županije. Tom prilikom oštećene su brojne povijesne zgrade u kojima su bile smještene ustanove u kulturi i obrazovanju, a knjižnice u njima, zbog sigurnosti zaposlenika i korisnika, privremeno su prestale s radom. Dodatni izazov predstavljao je rad na saniranju prostora knjižnica, zaštiti građe i vraćanje knjižnica u funkcionalno stanje, a sve u okolnostima propisanih epidemioloških mjera zbog bolesti Covid-19. U radu će se opisati kategorizacija oštećenja koja su nastala na zgradama u kojima su djelovale pojedine knjižnice, rad knjižničara u posebnim okolnostima i prilagodba postojećih, kao i razvoj novih knjižničnih usluga. Značajna stručna pomoć i podrška knjižničarima na potresom pogođenim područjima kontinuirano je dolazila od Hrvatskog zavoda za knjižničarstvo, koji djeluje pri Nacionalnoj i sveučilišnoj knjižnici u Zagrebu, kao i od strukovnih knjižničarskih udruga.
\end{abstract}

Ključne riječi: potres, pandemija Covid-19, Zagreb, Petrinja, Hrvatska, knjižnice, knjižnične zgrade, online usluge

Uvod

Ovaj rad nastao je nakon razgovora s kolegama izvan Zagreba i Hrvatske i potrebe da se knjižničarskoj zajednici približe situacije u kojima su se našli knjižničari na području Zagreba i Sisačko-moslavačke županije, područjima koja su tijekom 2020. godine bila pogođena potresom i poplavom, a sve u pandemijskim uvjetima. Izazovi pred kojima su se našli knjižničari nisu bili samo na profesionalnom planu. Mnogi su knjižničari bili osobno pogođeni potresom, brinuli su o vlastitom životu, životnim uvjetima i sigurnosti svojih obitelji, a istovremeno su imali obavezu biti dostupni korisnicima, posebice učenicima i studentima, koji su i sami živjeli i učili u izvanrednim okolnostima.

Programi koje knjižnice nude, knjižnična građa koju knjižnice nabavljaju, kao i usluge koje knjižničari osmišljavaju - izravan su odgovor na potrebe korisnika. No, ovoga puta sigurnost i briga za zdravlje bili su na prvom mjestu.

\section{Knjižnice poslije potresa}

Tijekom 2020. godine, za knjižničare u pet županija u Hrvatskoj bilo je izuzetno zahtjevno razdoblje jer su, osim u uvjetima pandemije bolesti Covid-19, radili i u izvanrednim okolnostima poslije dvaju razornih potresa.

Potres koji se dogodio 22. 3. 2020. godine pogodio je područje Grada Zagreba, Zagrebačke i Krapinsko-zagorske županije upravo na početku dvadesetosmodnevnog potpunog zatvaranja (eng. lockdown) svih državnih i javnih ustanova te javnog prijevoza zbog pandemije bolesti Covid-19. Izrazito jak potres s epicentrom u Markuševcu, udaljenom tek sedam kilometara od središta Zagreba, bio je magnitude 5,5 po Richteru, a nakon njega ubrzo je uslijedilo još više snažnih potresa. Nekoliko su mjeseci još trajala podrhtavanja tla, no ti prvi potresi bili su najsnažniji 
i uzrokovali su veliku štetu na području gotovo cijelog Zagreba, a najviše su stradale povijesne zgrade u središtu grada. Teško su oštećene mnoge ustanove u kulturi i obrazovanju, kazališta, muzeji, fakulteti, škole i instituti, kao i knjižnice u njima, koje su na neko vrijeme u potpunosti prestale s radom dok se ne utvrdi stupanj oštećenja, odnosno sigurnost boravka u prostorima knjižnica. ${ }^{1}$

Statičari su, čim je to bilo moguće, izašli na teren i krenuli sa pregledavanjem zgrada ${ }^{2}$ koje su, ovisno o oštećenjima, dobile oznake: „crveno" - neuporabljivo zbog strukturnih oštećenja, „žuto" - privremeno neuporabljivo ili "zeleno" - uporabljivo bez ograničenja. ${ }^{3}$

Najteže su stradale zgrade Sveučilišta u Zagrebu, posebice glavna zgrada Pravnog fakulteta s Rektoratom i dijelom Knjižnice Pravnog fakulteta, koja se zbog potresa pomaknula 10 centimetara i dobila crvenu oznaku. Žutu oznaku dobila je zgrada Pravnog fakulteta u kojoj je smješten odjel periodike s čitaonicom te zgrada Studijskog centra socijalnog rada s područnom knjižnicom. U potresu je teško stradala i zgrada Medicinskog fakulteta, uključujući i Središnju medicinsku knjižnicu koje su označene crvenom oznakom, a još je sedam visokih učilišta i njihovih knjižnica označeno privremeno neuporabljivima.

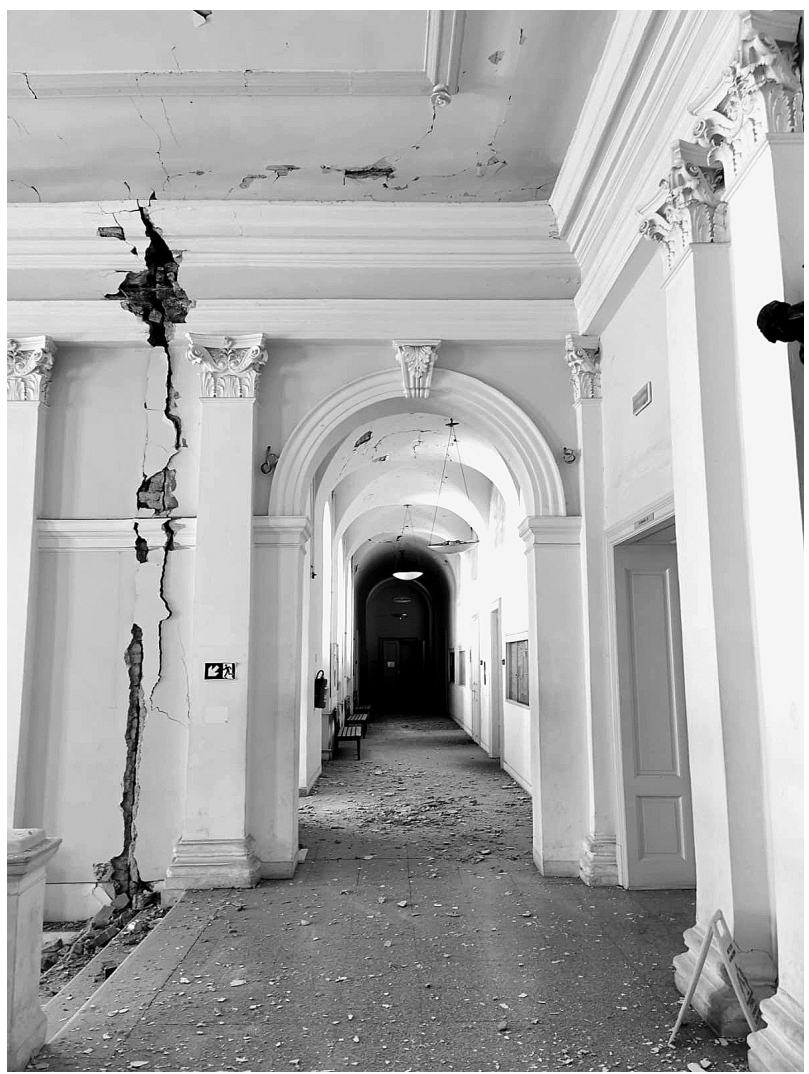

Slika 1. Unutrašnjost glavne zgrade Pravnog fakulteta i Rektorata ${ }^{4}$

\footnotetext{
1 Marta Šavor Novak i dr., „Potres u Zagrebu od 22. ožujka 2020. - preliminarni izvještaj o seizmološkim istraživanjima i oštećenjima zgrada“, Građevinar 72 (10) (2020): 843-867, preuzeto 10. 11. 2020, doi: https://doi.org/10.14256/JCE.2966.2020.

2 Prvotno su na zgradama oštećenim u potresu provedeni brzi pregledi statičara, u kojima su, radi zaštite sigurnosti stanovnika i zaposlenika, zgrade razvrstane prema stupnju oštećenja. Poslije toga je proveden još jedan, a prema potrebi i više, detaljnijih pregleda statičara.

3 Stambeni ZG d.o.o., „Potres: značenje oznaka nakon provedenog brzog pregleda statičara“, Stambeni ZG upravljanje i održavanje zgrada, preuzeto 3. 9. 2021, http://stambenizg.hr/wp-content/uploads/2020/03/Potres-pojasnjenje-oznaka-nakon-pregleda.pdf.

${ }_{4}^{4}$ Narod HR, preuzeto 1. 9. 2021, https://narod.hr/wp-content/uploads/2020/03/pravni-fakultet-potres-768x1024.jpg.
} 
Potresom je oštećen najveći broj specijalnih knjižnica koje su smještene u institutima, zavodima, arhivima, muzejima ili bolnicama. Gotovo svih 60 specijalnih knjižnica, koliko je na području Zagreba, izvijestilo je o štetama na knjižničnim zgradama i prostorima, građi i opremi. Od muzejskih, najviše su oštećene knjižnice Hrvatskoga školskog muzeja, Hrvatskoga povijesnog muzeja i Hrvatskoga športskog muzeja (označene su neuporabljivima). Privremeno neuporabljivima kategorizirano je 10 muzeja i Muzejsko dokumentacijski centar. Neuporabljivom je proglašena i zgrada Instituta za staroslavenski jezik u palači Škrlec-Balbi na Gornjem gradu u kojoj je bila Knjižnica s bogatom zbirkom stare i rijetke građe. Znatno su oštećene Knjižnica Odsjeka za povijesne znanosti i Knjižnica Jadranskog zavoda u palači Hrvatske akademije znanosti i umjetnosti, Knjižnica Državnoga hidrometeorološkog zavoda i Instituta za razvoj i međunarodne odnose, kao i zgrada Hrvatskoga glazbenog zavoda.

Knjižnica Franjevačkoga samostana zbog velikih je oštećenja preseljena, dok su Knjižnica i arhiv židovske vjerske zajednice „Bet Israel“ i Centralna biblioteka Srba u Republici Hrvatskoj postale privremeno neuporabljive. ${ }^{5}$

Među knjižnicama oštećenima u potresu bila je i Gradska knjižnica (iz mreže Knjižnica grada Zagreba), koja je smještena u zgradi iz 1895. godine. Nakon pregleda statičara i uklanjanja dimnjaka kojima je prijetilo urušavanje, a time i veća šteta na Knjižnici, sama zgrada dobila je zelenu oznaku. Osim nje, još je 18 knjižnica u mreži Knjižnica grada Zagreba dobilo dopuštenje za korištenje, odnosno nastavak rada unatoč oštećenjima koja treba sanirati. No, dvije su knjižnice dobile žutu oznaku kao privremeno neuporabljive.

Nakon potresa, manja je oštećenja imala Nacionalna i sveučilišna knjižnica u Zagrebu, ali su zato posebno stradale brojne škole. Prema Izvješću o štetama na odgojno-obrazovnim objektima Gradskog ureda za obrazovanje Grada Zagreba, dvije osnovne i dvije srednje škole dobile su crvenu oznaku, žutom oznakom označeno je 10 srednjih i 16 osnovnih škola, dok je 119 školskih objekata proglašeno upotrebljivim sa oštećenjima. ${ }^{6}$ Prostor knjižnica u pojedinim školama postao je neuporabljiv ili djelomično neuporabljiv zbog pukotina na zidovima i stropovima, dok namještaj, oprema i građa uglavnom nisu bili oštećeni.

lako je teža oštećenja pretrpjelo nekoliko područnih škola Krapinsko-zagorske i Zagrebačke županije, oštećenja u školskim knjižnicama nije bilo. Štetu nastalu od potresa prijavila je i Knjižnica Pučkog otvorenog učilišta Donja Stubica u Krapinsko-zagorskoj županiji.

Uz teške uvjete rada u knjižnicama zbog potresa i ograničenja, odnosno propisanih epidemioloških mjera koje su se gotovo svakodnevno mijenjale, krajem srpnja 2020. knjižničari su se našli pred novim izazovom. Dodatne štete u knjižnicama iz mreže Knjižnica grada Zagreba prouzročile su poplave u noći s 24. na 25. 7. 2020. godine, uglavnom u podrumskim spremištima knjižne građe.

Tri su knjižnice u Koprivničko-križevačkoj županiji (Gradska knjižnica "Franjo Marković" Križevci, Narodna knjižnica Virje i Gradska knjižnica Đurđevac) prijavile značajnu štetu nakon nevremena s kišom i tučom koje je bilo na tom području 29. i 30. 8. 2020. ${ }^{7}$

U razornome potresu magnitude 6,2 prema Richteru koji je 29. 12. 2020. godine pogodio područje Petrinje, Siska i Gline, kao i nizu slabijih naknadnih potresa, stradao je veći broj knjižnica na području Sisačko-moslavačke županije. Najveću štetu pretrpjela je Gradska knjižnica i čitaonica Petrinja te Dječji odjel Narodne knjižnice i čitaonice „Vlado Gotovac" Sisak.

\footnotetext{
${ }^{5}$ Frida Bišćan i dr., „Posljedice potresa u knjižnicama u Zagrebu i susjednim županijama“, HKD Novosti 83 (2020), preuzeto 2. 9. 2021, https://www.hkdrustvo.hr/hkdnovosti/clanak/1689.

${ }^{6}$ Gradski ured za odgoj i obrazovanje, Izvješće o štetama na odgojno-obrazovnim objektima Gradskog ureda za obrazovanje Grada Zagreba, Grad Zagreb, preuzeto 2. 9. 2021, https://www.zagreb.hr/izvjesce-o-stetama-na-odgojno-obrazovnim-objektima/157532.

${ }^{7}$ Frida Bišćan i dr., „Posljedice potresa i poplava u knjižnicama u Zagrebu i susjednim županijama“, Glas NSK Godina 7, broj 17 (2020): 15-17, preuzeto 30. 8. 2021, https://www.nsk.hr/ispis-rezultata/.
} 


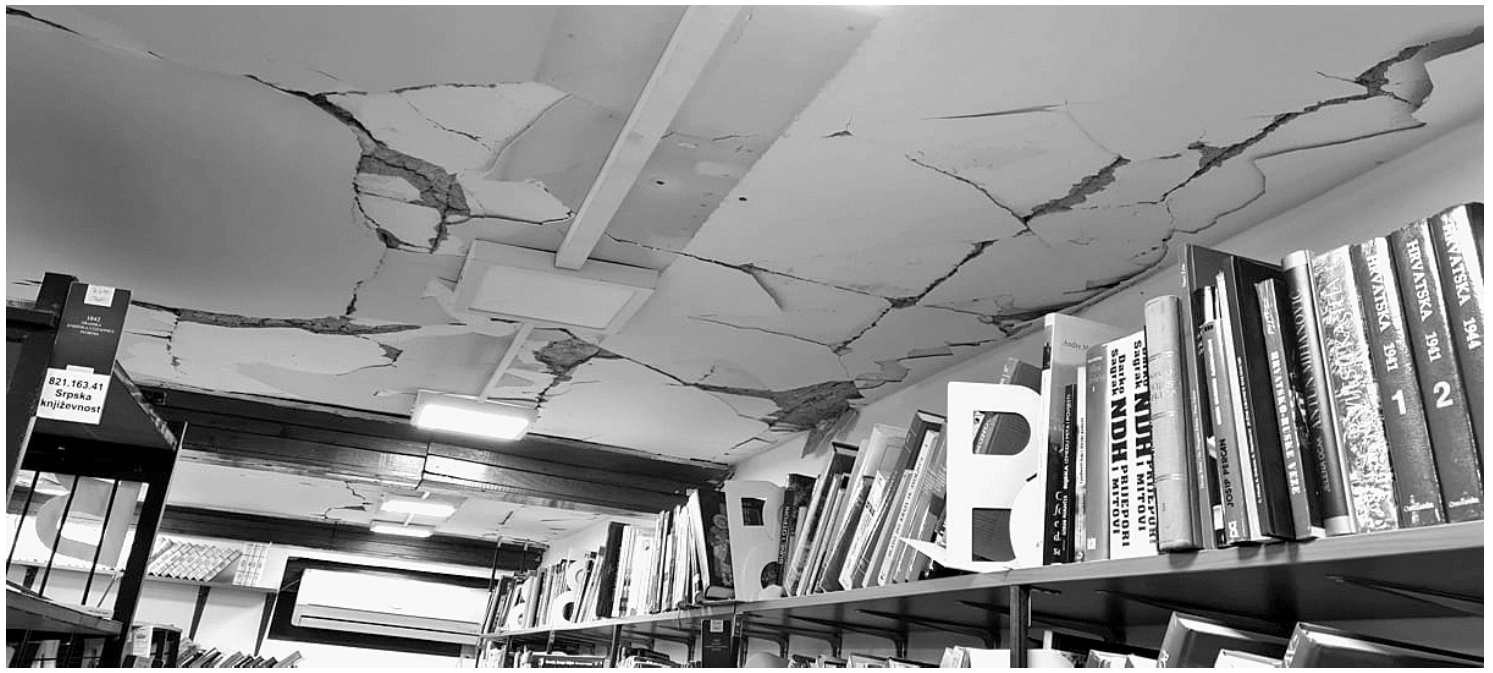

Slika 2. Gradska knjižnica i čitaonica Petrinja poslije potresa ${ }^{8}$

Knjižnica Učiteljskog fakulteta Sveučilišta u Zagrebu - Odsjek Petrinja, u potresu je oštećena toliko da ulaz u nju nije bio dopušten, već je samo izdvojen dio najvrijednije građe i pohranjen u Nacionalnu i sveučilišnu knjižnicu u Zagrebu.

Poslije tog potresa, dodatna oštećenja pretrpjelo je i dvanaest knjižnica u mreži Knjižnica grada Zagreba, kao i nekoliko knjižnica u Karlovačkoj i Zagrebačkoj županiji. Tijekom tzv. petrinjskog potresa značajno je oštećeno više škola na području Zagrebačke županije, a time i školskih knjižnica.

\section{Knjižničari u izazovnom vremenu}

Mnogi knjižničari bili su privatno pogođeni potresom, ostali su bez domova, morali su privremeno iseliti iz oštećenih zgrada, kuća i stanova te brinuti o sigurnosti vlastite obitelji. Istovremeno na poslu, u knjižnicama, nisu imali dobre uvjete za rad. Knjižnice u kojima su radili bile su više ili manje oštećene. U nekim slučajevima bilo je potrebno organizirati rad na daljinu i nastaviti pružati usluge korisnicima. Potrebe korisnika za vrijeme pandemije, kao i poslije potresa, bile su različite, učenici su bili na kraju školske godine, srednjoškolci su trebali literaturu za polaganje mature i upis na fakultet, a studenti su, bez obzira na sve okolnosti, trebali imati dostupnu stručnu literaturu za polaganje ispita i pisanje stručnih i diplomskih radova. U ovom iznimno stresnom periodu korisnici narodnih knjižnica posegnuli su za tiskanim knjigama, ali i otkrili blagodati posudbe elektroničkih knjiga.

Spašavanje knjižnične opreme i građe u nekim je slučajevima bilo nemoguće zbog (ne)sigurnosti, odnosno opasnosti od urušavanja zgrade, na primjer u Petrinji i Glini, pa su školske knjižnice započele rad u drugim školama, ali bez vlastite knjižnične građe.

Knjižnica Filozofskog fakulteta Sveučilišta u Zagrebu je poslije pregleda statičara označena zelenom oznakom, no pretrpjela je znatnu štetu jer su popucali zidovi, razbijena je stropna rasvjeta, djelomično je uništen spušteni strop itd. Najveći problem bio je taj što su se na višim katovima Knjižnice u potpunosti srušile police s knjigama i oko 130.000 svezaka knjižne građe odjednom je postalo nedostupno. Tijekom sanacije knjižnice, odnosno učvršćivanja polica i

\footnotetext{
${ }^{8}$ Gradska knjižnica i čitaonica Petrinja, „Prva hrvatska kontejnerska knjižnica“, Facebook. 2. 9. 2021, https://www.facebook.com/ GradskaKnjiznicalCitaonicaPetrinja/.
} 
organizacije građe na njima, knjižničari su zbog poštivanja epidemioloških uvjeta radili u timovima. Svaki se zaposlenik odlučivao, prema vlastitom osjećaju osobne sigurnosti, što će i gdje raditi. Pojedini knjižničari bojali su se ući među police, što je posebno došlo do izražaja kad su se tek složene police srušile na jednu knjižničarku. S druge strane, takvo stresno okruženje, na radnom mjestu i kod kuće, potaknuli su kod većine zaposlenika potrebu za boljim međusobnim povezivanjem, pružanjem podrške i osjećaja sigurnosti u knjižnici. O osjećaju sigurnosti na radnom mjestu za vrijeme potresa i pandemije provedeno je istraživanje u Knjižnici Filozofskog fakulteta Sveučilišta u Zagrebu. Rezultati istraživanja pokazali su da je osjećaj sigurnosti na radnom mjestu jako važan svakom zaposleniku, ali pri tome ispitanici nisu jasno istaknuli osjećaju li se više ili manje sigurno na radnom mjestu zbog potresa ili pandemije. Knjižničari su odgovornost za osjećaj sigurnosti podijelili na osobnu odgovornost zaposlenika, ali i na odgovornost ustanove smatrajući da bi uprava trebala jasnije komunicirati i poduzeti jače mjere sigurnosti u takvim izvanrednim okolnostima. ${ }^{9}$ Knjižničari su rijetko ispitanici u ovakvim situacijama jer knjižnice, prema procjenama sigurnosti na radu, nisu posebno rizična skupina radnih mjesta. No, 2020. godina bila je uistinu posebna.

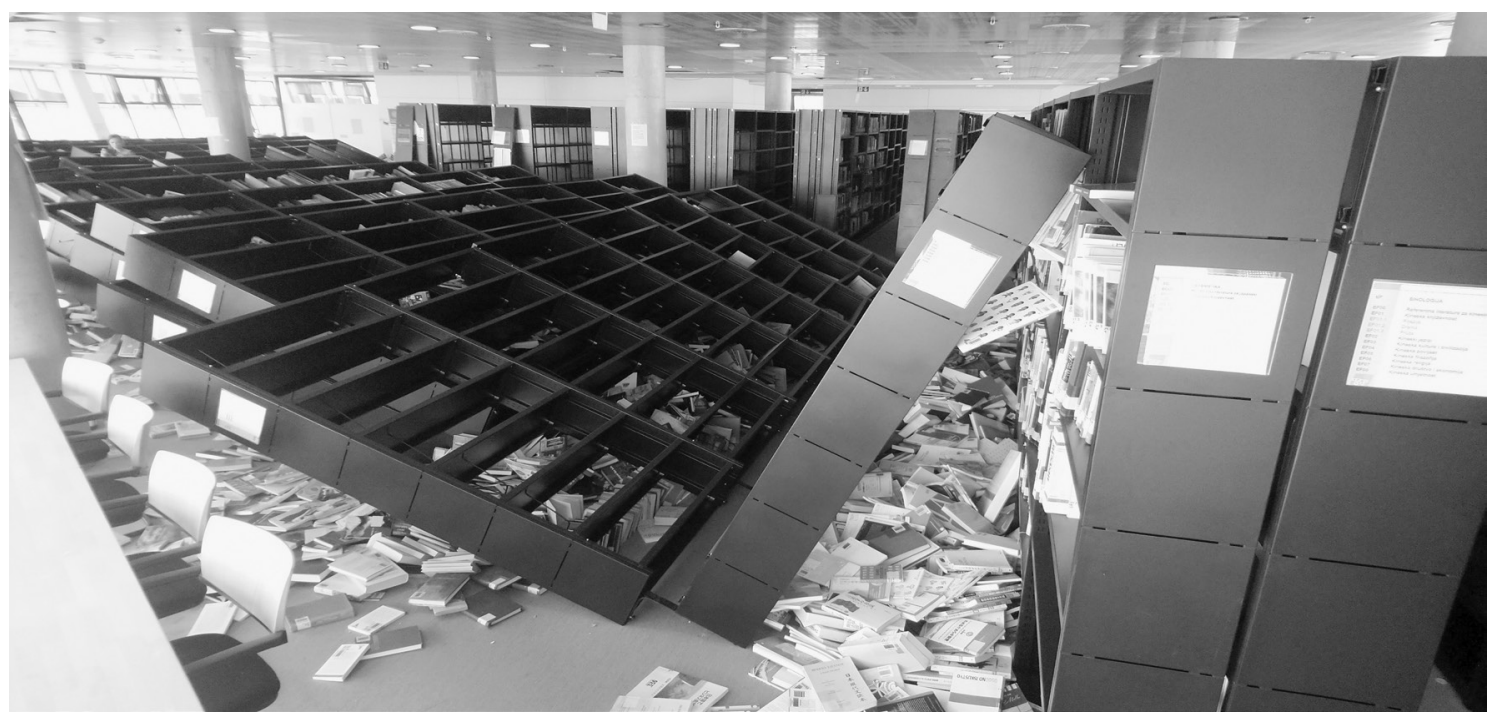

Slika 3. Knjižnica Filozofskog fakulteta u Zagrebu poslije potresa 22. 3. 2020.

\section{Nove i/ili poboljšane online usluge}

Izvanredna situacija izazvana pandemijom bolesti Covid-19, kao i potresima u 2020. godini, utjecala je i na usluge koje različite vrste knjižnica pružaju svojim korisnicima. Virtualne usluge koje su postojale i ranije tek su u 2020. godini korisnici prepoznali kao važne i korisne zbog nemogućnosti osobnog dolaska u knjižnicu. Primjerice, posudba e-knjiga u Knjižnicama grada Zagreba korištenjem prve hrvatske knjižnične aplikacije Zaki Book ${ }^{10} \mathrm{~s}$ radom je započela sredinom 2019. godine, u siječnju 2020. imala je 1212 korisnika, a do travnja iste godine njihov je broj porastao

\footnotetext{
9 Dorja Mučnjak i Višnja Novosel, „Dva volana - mentalno zdravlje djelatnika i upravljanje u knjižnicama pogođenim pandemijom i potresom: studija slučaja jedne visokoškolske knjižnice“", Vjesnik bibliotekara Hrvatske 64, 1 (2021): 81-94, preuzeto 1. 9. 2021, https://www.hkdrustvo.hr/vjesnik-bibliotekara-hrvatske/index.php/vbh/article/view/854/713.

10 Zaki Book je dio integriranog knjižničnog sustava Zaki i omogućuje posudbu e-knjige za članove knjižnice. Za prijavu se koristi broj iskaznice i PIN koji korisnik može dobiti u svojoj knjižnici.
} 
na 4819. ${ }^{11}$ Zaki Book-om se omogućilo korisnicima starijima od 15 godina da odaberu između 1000 naslova i posude po dvije knjige istovremeno (na 21 dan), a maksimalno pet u jednom mjesecu. U 2021, godini koja je proglašena Godinom čitanja u Hrvatskoj, uvedena je posudba e-knjiga za djecu. Knjižnice grada Zagreba su zbog potresa, a druge knjižnice zbog pandemije ${ }^{12}$ i nemogućnosti fizičkog dolaska korisnika u knjižnicu, pokrenule novu uslugu - online upis, odnosno online obnovu članstva. Na taj način su korisnici mogli od kuće iskoristiti ove usluge te odmah započeti s posudbom e-knjiga. ${ }^{13}$

Mnoge tribine i čitateljski klubovi, koji su se do pandemije i potresa održavali u fizičkim prostorima narodnih knjižnica, „preselili“ su u virtualni prostor, a zbog potrebe za komunikacijom uživo, živahnijih i poticajnijih rasprava te komunikacije sudionika s publikom ubrzo su takva događanja postala hibridna, sa naknadno stalno dostupnim snimkama. ${ }^{14}$

U visokoškolskim i specijalnim knjižnicama dodatno je proširena podrška korisnicima na daljinu, a školski knjižničari su, osim postojećih mrežnih stranica, napravili i stranice virtualne knjižnice koje je na jednom mjestu popisala Hrvatska mreža školskih knjižničara. ${ }^{15}$ Konačno su školski knjižničari mogli praktično pokazati svoje informatičke vještine, kao i digitalnu i informacijsku pismenost te su mnogim učiteljima i nastavnicima pomagali u svladavanju online alata i tako postali stalno prisutni u virtualnim učionicama.

Sve vrste knjižnica počele su više i kvalitetnije koristiti stranice koje su od prije imale na društvenim mrežama. Primjerice, na Facebook-u knjižnice više nisu samo najavljivale događanja iz svojih knjižnica, već su dijelile događanja domaćih i stranih kulturnih ustanova i udruga, stvarale su vlastiti sadržaj, a postale su i izvor informacija o stanju knjižnica, odnosno privremenom zatvaranju ili otvaranju pojedine knjižnice. ${ }^{16} \mathrm{Na}$ raznim kanalima društvenih mreža knjižnice su za djecu osmislile zabavne i kreativne sadržaje - escape room, online kvizove i pričanje priča, ali i pozivale male korisnike da preuzmu u knjižnici paketiće s materijalima za kućne radionice. U 2020. godini knjižničari Knjižnice Medveščak (Knjižnice grada Zagreba) snimali su i objavljivali upute za samostalan kreativni rad kod kuće, ${ }^{17}$ a potom su tijekom 2021. godine nastavili suradnju sa dječjim vrtićima pripremajući pakete slikovnica s materijalom za kreativne radionice koje su djeca odnosila u vrtić. Dječjim radovima nastalim u vrtiću poslije čitanja ukrašavani su izlozi knjižnice. ${ }^{18}$

Također, mnoge knjižnice uvode tzv. knjigomate za povrat knjiga i sigurnije poslovanje za vrijeme pandemije. Usluga knjigomata korisnicima je dostupna i izvan radnog vremena knjižnice, a primjerice, za korištenje knjigomata Gradske knjižnice „Ivan Goran Kovačić” u Karlovcu nije potrebno nositi člansku iskaznicu. U slučaju da korisnik ima zakasninu za vraćene knjige, može ju podmiriti pri idućem dolasku u knjižnicu. ${ }^{19}$

\footnotetext{
11 Knjižnice grada Zagreba, „Izvještaj o radu 2020.“, 10, preuzeto 1. 9. 2021, https://issuu.com/knjinicegradazagreba/docs/ izvjestaj_2020_web.

12 Primjerice, Gradska knjižnica Rijeka, Gradska knjižnica i čitaonica Vinkovci i dr.

13 Dina Mašina Delija i Dunja Holcer, „Aktivnosti hrvatskih narodnih knjižnica na Facebooku u uvjetima proljetnog lockdowna 2020.", Vjesnik bibliotekara Hrvatske 64, 1 (2021): 95-110, preuzeto 30. 8. 2021, doi: https://www.hkdrustvo.hr/vjesnik-bibliotekara-hrvatske/index.php/vbh/article/view/859/714

${ }_{14}$ Primjer snimki raznih događanja u mreži Knjižnica grada Zagreba nalazi se na YouTube kanalu Knjižnica grada Zagreba, https:// www.youtube.com/user/KnjizniceZagreba/playlists.

15 Hrvatska mreža školskih knjižničara, „Virtualne na jednom mjestu“, preuzeto 30. 8. 2021, http://www.knjiznicari.hr/UDK02/index php/Virtualne_na_jednom_mjestu!.

16 Primjerice, Knjižnice grada Zagreba su redovito obavještavale korisnike koja je knjižnica zatvorena zbog pregleda statičara, od kad započinje s redovitim radom i sl.

17 Knjižnice grada Zagreba, Knjižnica Medveščak, „Izradi ukras za jelku“, preuzeto 24. 9. 2021, https://fb.watch/8higgx/as0/.

18 Knjižnice grada Zagreba, Knjižnica Medveščak - Dječja knjižnica M2, "Skitamo i slikopričamo“, preuzeto 24. 9. 2021, http://www. $\mathrm{kgz.hr} / \mathrm{hr} /$ dogadjanja/skitamo-i-slikopricamo/57412.

${ }_{19}$ Gradska knjižnica „Ivan Goran Kovačić" u Karlovcu, Knjigomat, preuzeto 24. 9. 2021, http://www.gkka.hr/wp-content/uploads/2021/03/Tekst.pdf.
} 
Gradska knjižnica i čitaonica Petrinja je 7. 4. 2021. godine zbog „crvene oznake“ i nesigurnih uvjeta rada otvorila svoja vrata kao „Prva hrvatska kontejnerska knjižnica“, a stanovnicima Petrinje pomoć je pružena na daljinu iz Požege i Pule. ${ }^{20}$

Gradska knjižnica Požega ponudila je besplatan upis na godinu dana stanovnicima Petrinje, a time i korištenje svih online usluga, kao i posudbu e-knjiga na Zaki Book platformi. ${ }^{21}$ Gradska knjižnica i čitaonica Pula omogućila je stanovnicima Petrinje posudbu e-knjiga na platformi iBiblos. ${ }^{22}$

Knjižničarske su udruge također napravile iskorak od svoje redovite djelatnosti. Hrvatsko knjižničarsko društvo pokrenulo je tematski portal s ciljem prikupljanja i objavljivanja relevantnih informacija o posljedicama i utjecaju pandemije Covid-19 i potresa na hrvatske knjižnice. ${ }^{23}$

Zagrebačko knjižničarsko društvo ${ }^{24}$ je teme svojih ZKD foruma ${ }^{25}$ prilagodilo trenutnoj kriznoj situaciji. Krajem 2020. godine organiziran je ciklus od tri predavanja s radioničkim dijelom zajedničkog naziva "U potrazi za izgubljenim živcima“. Tim ciklusom nastojalo se osnažiti pojedince, osvijestiti važnost i načine komunikacije u stresnim situacijama, u obiteljskom i radom okruženju. U siječnju 2021. godine održan je ZKD forum "Niz nesretnih događaja: krizno knjižničarstvo" na kojem su stručnjaci različitih područja govorili o važnosti učinkovitog kriznog menadžmenta na svim razinama, od državne i lokalne uprave, u sredinama u kojima radimo, pa do obiteljske i osobne razine. ${ }^{26}$

\section{Zaključak}

Knjižnice i knjižničari u Hrvatskoj su tijekom 2020. godine živjeli i radili u iznimno zahtjevnim uvjetima. Pandemija i poštivanje propisanih epidemioloških mjera znatno su otežali rad knjižničara na zbrinjavanju i zaštiti knjižničnog fonda poslije potresa, pri čemu se uvijek brinulo da korisnicima budu dostupne knjižnične usluge. Knjižničarima su pritom koristili razni protokoli o postupanju s građom u kriznim situacijama i planovi evakuacije, a dodatno su provedene vježbe izlaska u slučaju opasnosti.

Veliku podršku knjižnicama pružila je Nacionalna i sveučilišna knjižnica u Zagrebu, odnosno Hrvatski zavod za knjižničarstvo. Prvotno je Zavod, na temelju preporuka Hrvatskog zavoda za javno zdravstvo, ${ }^{27}$ kontinuirano izrađivao smjernice i preporuke o radu knjižnica u uvjetima bolesti Covid-19. ${ }^{28}$ Poslije potresa je Zavod, u skladu s prostornim mogućnostima Nacionalne i sveučilišne knjižnice u Zagrebu, organizirao privremeni prihvat i pohranu dijela najvrjednije građe knjižnica oštećenih u potresu (npr. Knjižnice Instituta za staroslavenski, Gimnazije „Tituš Brezovački", Knjižnice Učiteljskog fakulteta iz Petrinje i dr.).

${ }^{20}$ Gradska knjižnica i čitaonica Petrinja, „Kontejnerska knjižnica na lokaciji parkirališta rukometnog igrališta kojeg odnedavno nazivamo i trgom kulture", Gradska knjižnica i čitaonica Petrinja, preuzeto 30. 8. 2021, https://www.gkc-petrinja.hr/cms/.

${ }^{21}$ Požeški vodič: informativni portal, „Gradska knjižnica Požega Petrinjcima besplatan upis na godinu dana za čitanje e-knjiga“ , preuzeto 30. 8. 2021, https://pozeskivodic.com/gradska-knjiznica-pozega-petrinjcima-besplatan-upis-na-godinu-dana-za-citanje-e-knjiga/.

22 Gradska knjižnica i čitaonica Petrinja, "Gradska knjižnica i čitaonica Pula, Gradskoj knjižnici i čitaonici Petrinja“, Gradska knjižnica i čitaonica Petrinja, preuzeto 30. 8. 2021, https://www.gkc-petrinja.hr/cms/

${ }^{23}$ Hrvatsko knjižničarsko društvo, „Knjižnice u doba COVID-19“, preuzeto 30. 8. 2021, http://covid19.hkdrustvo.hr/.

${ }^{24}$ Zagrebačko knjižničarsko društvo. "ZKD forum“, preuzeto 30. 8. 2021, https://zkd.hr/zkd-forum/.

${ }^{25}$ ZKD forum je besplatan program edukacije i podrške knjižničarima iz svih vrsta knjižnica. Njegova temeljna ideja je konkretna i praktična pomoć knjižničarima zaposlenima u raznim vrstama knjižnica, ali i biti mjesto na kojem mogu raspraviti probleme iz svakodnevnog rada, pratiti trendove u struci te nadopunjavati svoja stručna znanja. ZKD forum se do epidemije bolesti Covid-19 održavao u Knjižnici Filozofskog fakulteta u Zagrebu, od listopada 2020. godine je zbog epidemioloških mjera, a potom i zbog potresa, postao virtualan, što je i danas.

${ }^{26}$ Snimka ZKD foruma „Niz nesretnih događaja: krizno knjižničarstvo“, YouTube, 27. siječnja 2021, objavljeno 8. 2. 2021, preuzeto 30. 8. 2021, https://www.youtube.com/watch?v=4rz1a9yiUxw\&list=PLxI1Q51LPITeTZL7dU43cnZXUH_rf_0Gs.

27 Hrvatski zavod za javno zdravstvo, "Korona virus - najnovije preporuke“, Hrvatski zavod za javno zdravstvo, preuzeto 1. 9. 2021, https://www.hzjz.hr/sluzba-epidemiologija-zarazne-bolesti/koronavirus-najnovije-preporuke/.

${ }_{28}$ Portal matične djelatnosti knjižnica u Republici Hrvatskoj, "Smjernice i preporuke za rad knjižnica“, Nacionalna i sveučilišna knjižnica u Zagrebu, preuzeto 3. 9. 2021, http://maticna.nsk.hr/covid-19/smjernice-i-preporuke-za-rad-knjiznica/. 
I u tako zahtjevnim okolnostima knjižničari su radili na poboljšanju postojećih i razvoju novih usluga, a knjižničarske udruge su svoje aktivnosti prilagodile novonastaloj situaciji.

Naravno da nije bilo jednostavno. Pojedinci su se različito nosili sa stresom, kod kuće i na poslu, ravnatelji i uprave knjižnica pokazali su jesu li, i kako su, spremni djelovati u kriznim situacijama. Trebalo je osigurati uvjete za siguran rad knjižničara i u uvjetima nakon potresa i poplave, a opet sve u skladu sa propisanim epidemiološkim mjerama. Ponekad su smjernice i preporuke o radu knjižnica bile preopćenite, a u nekim knjižnicama i neprovedive. Velik problem nastao je u knjižnicama instituta, fakulteta i muzeja u središtu Zagreba koje su u kratkom roku trebale preseliti građu na sigurno, a pitanja su samo izvirala (Gdje s tolikom građom?, S čime ju prevesti?, Kako ju organizirati u novom/privremenom prostoru da bude dostupna za korištenje?, Koliko dugo će trajati „privremeno stanje“? ...). Školski knjižničari su isto radili u otežanim uvjetima. Niži razredi u osnovnim školama imali su nastavu uživo, viši uglavnom ne, a srednje škole mogle su obirati model prema kojem će raditi (uživo, hibridno, u potpunosti online). Povremeno su cijeli razredi bili u (samo)izolaciji. Četiri srednje i tri osnovne škole, a s njima i školske knjižnice, postale su podstanari u školama koje su imale mjesta privremeno ih prihvatiti (na dvije godine), dok se njihove zgrade ne saniraju. No, posebno složenu situaciju ima knjižničarka Osnovne škole "Petra Zrinskog" koja djeluje na pet različitih lokacija u Zagrebu.

Obnova u Gradu Zagrebu i županijama pogođenim potresom odvijat će se postupno i dugo, prema unaprijed utvrđenim prioritetima, od stambenih objekata i zdravstvenih ustanova do obrazovnih i kulturnih ustanova. Nažalost, obnova ne ide željenom brzinom zbog velikog broja oštećenih zgrada, kao i složenog procesa obnove zgrada s povijesnom i kulturnom vrijednošću. Zgrade će se obnoviti, no, posljedice koje će višegodišnji stres ostaviti na svima nama tek ćemo vidjeti.

\section{Literatura i izvori:}

1. Bišćan, Frida, Dunja Marija Gabriel, Aleksandra Pikić i Breza Šalamon Cindori. „Posljedice potresa u knjižnicama u Zagrebu i susjednim županijama“. HKD Novosti 83 (2020). Preuzeto 2. 9. 2021. https:// www.hkdrustvo.hr/hkdnovosti/clanak/1689.

2. Bišćan, Frida, Dunja Marija Gabriel, Goranka Mitrović, Aleksandra Pikić i Breza Šalamon Cindori. „Posljedice potresa i poplava u knjižnicama u Zagrebu i susjednim županijama", Glas NSK Godina 7, broj 17 (2020): 15-17. Preuzeto 30. 8. 2021. https://www.nsk.hr/ispis-rezultata/.

3. Gradska knjižnica i čitaonica Petrinja. „Gradska knjižnica i čitaonica Pula, Gradskoj knjižnici i čitaonici Petrinja“. Gradska knjižnica i čitaonica Petrinja. Preuzeto 30. 8. 2021. https://www.gkc-petrinja.hr/cms/.

4. Gradska knjižnica i čitaonica Petrinja. „Kontejnerska knjižnica na lokaciji parkirališta rukometnog igrališta kojeg odnedavno nazivamo i trgom kulture". Gradska knjižnica i čitaonica Petrinja. Preuzeto 30. 8. 2021. https://www.gkc-petrinja.hr/cms/.

5. Gradska knjižnica i čitaonica Petrinja. „Prva hrvatska kontejnerska knjižnica“. Facebook. 2. 9. 2021. https://www.facebook.com/GradskaKnjiznicalCitaonicaPetrinja/.

6. Gradska knjižnica "Ivan Goran Kovačić" u Karlovcu. Knjigomat. Preuzeto 24. 9. 2021. http://www.gkka. hr/wp-content/uploads/2021/03/Tekst.pdf.

7. Gradski ured za odgoj i obrazovanje. Izvješće o štetama na odgojno-obrazovnim objektima Gradskog ureda za obrazovanje Grada Zagreba. Grad Zagreb. Preuzeto 2. 9. 2021. https://www.zagreb.hr/ izvjesce-o-stetama-na-odgojno-obrazovnim-objektima/157532.

8. Hrvatska mreža školskih knjižničara. „Virtualne na jednom mjestu“. Preuzeto 30. 8. 2021. http://www. knjiznicari.hr/UDK02/index.php/Virtualne_na_jednom_mjestu!.

9. Hrvatski zavod za javno zdravstvo. „Korona virus - najnovije preporuke“. Hrvatski zavod za javno zdravstvo. Preuzeto 1. 9. 2021. https://www.hzjz.hr/sluzba-epidemiologija-zarazne-bolesti/ koronavirus-najnovije-preporuke/. 
10. Hrvatsko knjižničarsko društvo. „Knjižnice u doba COVID-19“. Preuzeto 30. 8. 2021. http://covid19. hkdrustvo.hr/.

11. Knjižnice grada Zagreba. „Izvještaj o radu 2020.“ Preuzeto 30. 8. 2021. https://issuu.com/ knjinicegradazagreba/docs/izvjestaj_2020_web.

12. Knjižnice grada Zagreba, Knjižnica Medveščak. „Izradi ukras za jelku“. Preuzeto 24. 9. 2021. https:// fb.watch/8higgxJas0/.

13. Knjižnice grada Zagreba, Knjižnica Medveščak - Dječja knjižnica M2. "Skitamo i slikopričamo“. Preuzeto 24. 9. 2021. http://www.kgz.hr/hr/dogadjanja/skitamo-i-slikopricamo/57412.

14. Mašina Delija, Dina i Dunja Holcer. „Aktivnosti hrvatskih narodnih knjižnica na Facebooku u uvjetima proljetnog lockdowna 2020.". Vjesnik bibliotekara Hrvatske 64, 1 (2021): 95-110. Preuzeto 30. 8. 2021. doi: https://www.hkdrustvo.hr/vjesnik-bibliotekara-hrvatske/index.php/vbh/article/view/859/714.

15. Mučnjak, Dorja i Višnja Novosel, „Dva volana - mentalno zdravlje djelatnika i upravljanje u knjižnicama pogođenim pandemijom i potresom: studija slučaja jedne visokoškolske knjižnice". Vjesnik bibliotekara Hrvatske 64, 1 (2021): 81-94. Preuzeto 1. 9. 2021. https://www.hkdrustvo.hr/vjesnik-bibliotekarahrvatske/index.php/vbh/article/view/854/713.

16. Narod HR. Preuzeto 1. 9. 2021. https://narod.hr/wp-content/uploads/2020/03/pravni-fakultet-potres768x1024.jpg.

17. Portal matične djelatnosti knjižnica u Republici Hrvatskoj. „Smjernice i preporuke za rad knjižnica“. Nacionalna i sveučilišna knjižnica u Zagrebu. Preuzeto 3. 9. 2021. http://maticna.nsk.hr/covid-19/ smjernice-i-preporuke-za-rad-knjiznica/.

18. Požeški vodič: informativni portal. „Gradska knjižnica Požega Petrinjcima besplatan upis na godinu dana za čitanje e-knjiga“. Preuzeto 30. 8. 2021. https://pozeskivodic.com/ gradska-knjiznica-pozega-petrinjcima-besplatan-upis-na-godinu-dana-za-citanje-e-knjiga/.

19. Snimka ZKD foruma. „Niz nesretnih događaja: krizno knjižničarstvo“. Youtube, 27. siječnja 2021. Objavljeno 8. 2. 2021, preuzeto 30. 8. 2021. https://www.youtube.com/watch?v=4rz1a9yiUxw\&list=PLxl 1Q51LPITeTZL7dU43cnZXUH_rf_0Gs.

20. Stambeni ZG d.o.o. „Potres: značenje oznaka nakon provedenog brzog pregleda statičara“. Stambeni ZG upravljanje i održavanje zgrada. Preuzeto 3. 9. 2021. http://stambenizg.hr/wp-content/uploads/2020/03/Potres-pojasnjenje-oznaka-nakon-pregleda.pdf.

21. Šavor Novak, Marta, Mario Uroš, Josip Atalić, Marijan Herak, Marija Demšić, Maja Baniček, Damir Lazarević, Nenad Bijelić, Milan Crnogorac i Mario Todorići. „Potres u Zagrebu od 22. ožujka 2020. - preliminarni izvještaj o seizmološkim istraživanjima i oštećenjima zgrada“. Građevinar 72 (10): 843-867. Preuzeto 10. 11. 2020. https://doi.org/10.14256/JCE.2966.2020.

22. Zagrebačko knjižničarsko društvo. „ZKD forum“. Preuzeto 30. 8. 2021. https://zkd.hr/zkd-forum/.

23. YouTube kanal Knjižnica grada Zagreba. Preuzeto 24. 9. 2021. https://www.youtube.com/user/ KnjizniceZagreba/playlists. 


\title{
Two in One - Pandemic and Earthquake in Croatian Libraries
}

\begin{abstract}
Summary
In 2020, two devastating earthquakes hit the area of the City of Zagreb and Sisak-Moslavina County. On that occasion, numerous historical buildings in which cultural and educational institutions have been placed were damaged. Due to the safety of employees and users, libraries within the institutions (schools, museums, etc.) were temporarily closed. Many librarians were affected by the quake in their private lives, too - some of them lost their homes, some had to move temporarily out of the damaged buildings, houses, and flats, or take care of the safety of their families. At the same time, at work, in their libraries, they did not have regular working conditions. An additional challenge was restoring library buildings, protecting the material, and returning the libraries to a functional state, all in the circumstances of the prescribed epidemiological measures due to the Covid-19 pandemic. Extraordinary circumstances caused by the pandemic and earthquakes have also affected the services provided to the users by the different types of libraries. Only in 2020, due to the impossibility of visiting libraries in person, did users recognize the importance and usefulness of virtual services that were available earlier as well. The paper describes the categorization of the damage caused to buildings in which some libraries operated, the work of librarians in special circumstances, and the adaptation of existing as well as the development of new library services. Significant professional assistance and support to librarians in the earthquake-affected areas have continuously been provided by the Croatian Institute of Librarianship, which operates at the National and University Library in Zagreb, as well as by professional library associations.
\end{abstract}

Keywords: earthquake, Covid-19 pandemic, Zagreb, Petrinja, Croatia, libraries, library buildings, online services

Примљено: 13. септембра 2021.

Нсправке рукописа: 27. септембра 2021

Прихваћено за објављивање: 2. октобра 2021. 